\title{
Aplikasi Mobile Layanan Bantuan Pengadilan Negeri Tondano
}

\author{
Rina Nurain Mokodompit ${ }^{1}$, Mohammad Rizky Mustain ${ }^{2}$, Ferjenia Feybelia ${ }^{3}$ \\ 1 Prodi Teknik Informatika UNIMA;2 Prodi Teknik Informatika UNIMA; 3 Prodi Teknik Informatika UNIMA \\ Email:17210013@unima.ac.id
}

\begin{abstract}
At present the use of mobile applications to help office work in various agencies, is a very important requirement. Like other district courts, the tondano district court still uses a manual system in terms of assistance services For example, visitors must wait for a long time to get information. The tondano district court assistance mobile application is very useful for employees, visitors, and developers of this application. This mobile application really help and easy used for tondano district court visitors to get information in the form of trial schedules, decision directories, ticket information, e-courts, and surveys conducted by tondano district courts. The research method used is the system development life cycle (SDLC). Testing this application uses black box testing which was tested by two people from the tondano district court with excellent testing results.
\end{abstract}

Keywords - Mobile Aplications, Assistance Service, Systems, SDLC, BlackBox Testing.

\begin{abstract}
Abstrak - Saat ini penggunaan aplikasi mobile untuk membantu pekerjaan kantor di berbagai instansi, sudah merupakan kebutuhan yang sangat penting. Seperti pengadilan negeri lainnya, pengadilan negeri tondano masih menggunakan sistem manual dalam hal layanan bantuan. Misalnya, pengunjung harus antri dengan waktu yang cukup lama untuk mendapatkan informasi.

Aplikasi mobile layanan bantuan pengadilan negeri tondano ini sangat berguna baik bagi pegawai, pengunjung, maupun pengembang aplikasi ini. Aplikasi mobile ini memudahkan pengunjung pengadilan negeri tondano untuk mendapatkan informasi berupa jadwal sidang, direktori putusan, informasi tilang, e-court, dan survei-survei yang diadakan oleh pengadilan negeri tondano. Metode penelitian yang digunakan adalah system development life cycle (SDLC). Pengujian aplikasi ini menggunakan pengujian black box yang diuji oleh dua orang dari pihak pengadilan negeri tondano dengan hasil pengujian yang sangat baik.
\end{abstract}

Kata Kunci-Aplikasi Mobile, Layanan Bantuan, Sistem, SDLC, Pengujian BlackBox.

\section{Pendahuluan}

Untuk pelayanan yang lebih efisien, Pengadilan Negeri Tondano memberlakukan sistem Pelayanan Terpadu Satu Pintu (PTSP). Sehingga, semua pengunjung dengan berbagai jenis laporan dilayani dalam satu ruangan yang sama. Sistem yang digunakan oleh PTSP dalam memberikan informasi kepada masyarakat yang mengunjungi PN Tondano masih menggunakan sistem manual, misalnya masyarakat yang datang harus mengantri dengan waktu yang cukup lama untuk mendapatkan informasi yang mereka butuhkan dan terhambatnya pengumpulan data kepuasan masyarakat. Kami pun mendapatkan request dari pihak Pengadilan Negeri Tondano untuk membuat sebuah aplikasi mobile Layanan Bantuan untuk Pengadilan Negeri Tondano yang berfungsi untuk membantu pengunjung dalam mendapatkan informasi mengenai jadwal sidang, perkara lalu lintas, putusan-putusan, biaya proses, dan survei-survei yang di buat oleh Pengadilan Negeri Tondano.

\section{LANDASAN TEORI}

\section{A. Pengertian Aplikasi}

Menurut Yuhefizar (2012) aplikasi merupakan program yang dikembangkan untuk memenuhi kebutuhan pengguna dalam menjalankan pekerjaan tertentu. Menurut Verman (2009, p57) aplikasi adalah seperangkat instruksi khusus dalam computer agar kita menyelesaikan tugas-tugas tertentu. Berdasarkan pendapat diatas, dapat disimpulkan bahwa aplikasi adalah perangkat lunak yang siap pakai dengan menjalankan instruksi-instruksi dari pengguna untuk menyelesaikan tugas-tugas seperti membuat laoran, percetakan dan lain-lain.

\section{B. Pengertian Mobil}

Menurut Burnette (2009) Mobile dapat diartikan sebagai perpindahan yang mudah dari suatu tempat ke tempat yang lain.

Berdasarkan pengertian diatas, dapat disimpulkan bahwa mobile adalah terminal telepon yang dapat berpindah dengan mudah dari suatu tempat ke tempat yang lain tanpa terjadi pemutusan atau terputusnya komunikasi.

\section{Pengertian Aplikasi Mobile}

Menurut Buyens (2001) aplikasi mobile berasal dari kata application dan mobile. Application yang artinya penerapan, lamaran, penggunaan. Secara istilah aplikasi adalah program siap pakai yang direka untuk melaksanakan suatu fungsi bagi pengguna atau aplikasi yang lain dan dapat digunakan oleh sasaran yang dituju sedangkan mobile dapat di artikan sebagai perpindahan dari suatu tempat ke tempat yang lain.

Sehingga, aplikasi mobile dapat diartikan sebagai aplikasi yang berjalan di mobile device. Dengan menggunakan aplikasi mobile dapat mempermudah pekerjaan misalnya browsing, belajar, dan pekerjaan kantor. 


\section{TAHAPAN METODE PENELITIAN}

Pada aplikasi ini kami menggunakan metode penelitian System Development Life Cycle (SDLC) dengan tahapan sebagai berikut :

a) Initiation and Feasibility Study (Inisiasi dan Fisibilitas) Pada tahap ini bertujuan untuk menentukan apakah suatu proyek cukup pantas dilanjutkan atau tidak, menentukan batasan-batasan sistem, serta membuat rencana permasalahan proyek yang berkaitan dengan lingkup permasalahan. Hasil dari tahap ini adalah Analisis kelayakan dan rencana proyek.

b) Analisis Sistem (System Analysis)

Pada fase ini akan menganalisis sistem yang sedang berjalan dalam perusahaan (sistem lama) juga mengindentifikasi kebutuhan-kebutuhan dan arahanarahan serta kesempatan yang diinginkan perusahaan untuk sistem baru yang akan dibangun.

c) Desain (Design)

Pada fase ini akan merancang kebutuhan interface dari sistem baru. Fase ini akan menghasilkan proses bisnis dari sistem baru.

d) Integrasi dan Pengujian (Integration and Test)

Pada tahap ini kami menggunakan pengujian black box sebagai hasil dari mendemonstrasikan perangkat lunak bahwa telah memenuhi kebutuhan yang dispesifikasikan pada dokumen kebutuhan fungsional.

\section{HASIL DAN PEMBAHASAN}

1. Phase I: Initiation and Feasibility Study

Tahap ini merupakan tahap dimana masih berupa tahap pengenalan suatu proyek yang akan dikerjakan yaitu berupa tahap konseptual atau pengenalan identitas suatu proyek. Biasanya pada tahap ini masih dilakukan suatu survei terhadap proyek yang akan direncanakan ke depan dan pengumpulan informasi yang dilakukan oleh suatu manajemen panitia, sehingga dapat memberikan suatu gambaran umum dari proyek yang akan dikerjakan.

Setelah melalui tahap konseptual atau pengenalan dari suatu proyek yang akan dilakukan maka tahap ini menganalisis apakah suatu proyek dapat dilaksanakan atau tidak (Feasible or Infeasible). Sehingga dapat dilanjutkan ke tahap berikutnya, jika proyek tersebut dinyatakan layak.

Pada tahap ini bertujuan untuk, menentukan apakah suatu proyek cukup pantas dilanjutkan atau tidak, menentukan batsan-batasan system, serta membuat rencana permasalahan proyek yang berkaitan dengan lingkup permasalahan. Hasil dari tahap ini adalah analisis kelayakan dan rencana proyek. Pada tahap ini ada beberapa langkah yang akan dilakukan, yaitu :

\section{A. Request Clarification}

1. Apa masalah yang dihadapi oleh perusahaan? Masyarakat ingin mengetahui informasi mengenai jadwal sidang, perkara lalu lintas, putusan-putusan, dan biaya proses.

2. Rincian masalah
- $\quad$ Masyarakat yang akan melapor perkara harus mengantri untuk mengetahui berapa biaya proses untuk perkaranya

- Banyak masyarakat yang masih kekurangan informasi mengenai jadwal sidangnya dan nomor perkara

3. Seberapa besar kesulitan masalah yang dihadapi? Belum ada aplikasi mobile layanan bantuan seperti ini sebelumnya, sehingga pegawai masih harus menyesuaikan diri dengan aplikasi dan device yang digunakan.

4. Bagaimana aplikasi layanan bantuan akan membantu? Aplikasi mobile layanan bantuan ini akan membantu :

- Untuk memudahkan masyarakat dalam mendapatkan informasi mengenai pengadilan negeri tondano, info tilang, jadwal sidang, Salinan putusan, dan biaya proses.

5. Bagaimana pendapat pengguna untuk solusi ini?

- Dalam solusi ini kami mendapatkan dukungan dari Sekretaris pengadilan negeri tondano untuk pembuatan proyek ini.

6. Siapa saja yang tahu dan dapat memberikan informasi mengenai pembuatan aplikasi layanan bantuan ini?

- Sekretaris PN Tondano

- Pegawai PTSP

- Staf Sub Bagian Umum dan Keuangan

- Hakim

B. Define objectives and scopes

Objectives :

Manfaat Kerja Praktek ada 2 yaitu :

1. Manfaat Teoritis

Menjadi referensi untuk Pengembangan Aplikasi

Layanan bantuan berbasis android.

2. Manfaat Praktis

- Penulis

Bisa menambah pengetahuan mengenai pembuatan aplikasi layanan bantuan berbasis android.

- Bagian PTSP Membantu jalannya aktifitas bagian PTSP menjadi lebih efektif dan memudahkan bagi banyak pihak baik pegawai maupun masyarakat yang mengunjungi pengadilan negeri tondano.

C. Set up feasibility study

1. Teknologi

- Teknologi yang dibutuhkan untuk menjalankan proyek ini sudah tersedia dan sesuai dengan yang dibutuhkan.

- Perangkat keras dan perangkat lunak yang dibutuhkan sudah tersedia.

- Aplikasi yang dirancang memiliki respon yang sesuai dengan keinginan klien.

- Aplikasi ini dapat di kembangkan untuk kebutuhan lebih luas lagi. 
2. Operasi

- Aplikasi berjalan dengan baik tanpa adanya eror.

- Aplikasi tidak mengganggu aktivitas pegawai.

3. Ekonomi

- Informasi yang didapatkan akurat.

Perangkat yang digunakan baik perangkat keras dan perangkat lunak sudah tersedia sehingga tidak memerlukan biaya tambahan.

D. Recommended Proceed

Setelah dianalisis maka tim kerja praktek merekomendasikan bahwa proyek ini layak untuk dilanjutkan

\section{E. Detailed Project Plan}

Project Organization :

Project Stakeholders

- System Owner : Pengadilan Negeri Tondano 1B

- System User : Masyarakat yang berkunjung ke PN Tdo

- System Designer

Story Board \& Layout : Ferjenia Feybelia

Logo : Mohammad Rizky Mustain

- System Programmer : Rina Nurain Mokodompit

Control Plans :

Quality Management

a. Standar Proyek

1) Semua dokumen akan dibuat sesuai format kerja praktek yang dikeluarkan oleh Program Studi Teknik Informatika, Universitas negeri Manado.

2) Magadakan pertemuan dengan klien sebaik mungkin dengan tim proyek.

3) Bekerja dengan staf yang berhubungan dengan proyek. b. Standar Teknologi

Teknologi yang digunakan adalah teknologi yang beradaptasi dengan sistem yang dikembangkan.

Communication Management

1) Dengan Klien Setiap hari, selama kerja praktek berjalan.

2) Antar Anggota Tim Semingu, 2 kali, yaitu Selasa dan Kamis

3) Dengan Dosen Sesuai dengan janji temu yang dibuat.

2. Phase 2 : Analysis System

A. Analyze User

Dalam pembuatan aplikasi ini, tim kerja praktek menghubungi pegawai Pelayanan Terpadu Satu Pintu untuk meminta informasi mengenai sistem yang sedang berjalan di Pengadilan Negeri Tondano 1B. Khususnya sistem layanan bantuan. Sistem ini akan digunakan oleh pegawai yang ada di PTSP dan masyarakat yang berkunjung.

TABEL I. ANALYZE USER

\begin{tabular}{|l|l|l|}
\hline NO & Aktor & Deskripsi \\
\hline
\end{tabular}

\begin{tabular}{|c|c|c|}
\hline 1 & $\begin{array}{l}\text { Staf bagian } \\
\text { umum dan } \\
\text { keuangan }\end{array}$ & $\begin{array}{l}\text { Orang yang } \\
\text { dipilih oleh } \\
\text { sekretaris } P N \\
\text { Tondano untuk } \\
\text { memelihara } \\
\text { device yang } \\
\text { digunakan untuk } \\
\text { menjalankan } \\
\text { aplikasi dan untuk } \\
\text { menjelaskan } \\
\text { proses bisnis dari } \\
\text { aplikasi ke } \\
\text { pengunjung PN } \\
\text { Tondano }\end{array}$ \\
\hline 2 & $\begin{array}{l}\text { Pengunjung } P N \\
\text { Tondano }\end{array}$ & $\begin{array}{l}\text { Orang yang } \\
\text { memiliki } \\
\text { kepentingan untuk } \\
\text { mendapatkan } \\
\text { informasi melalui } \\
\text { aplikasi layanan } \\
\text { bantuan PN } \\
\text { Tondano }\end{array}$ \\
\hline
\end{tabular}

B. Analyze The Current System

\section{Proses Bisnis}

Proses Bisnis Aplikasi Mobile Layanan Bantuan Pengadilan Negeri Tondano.

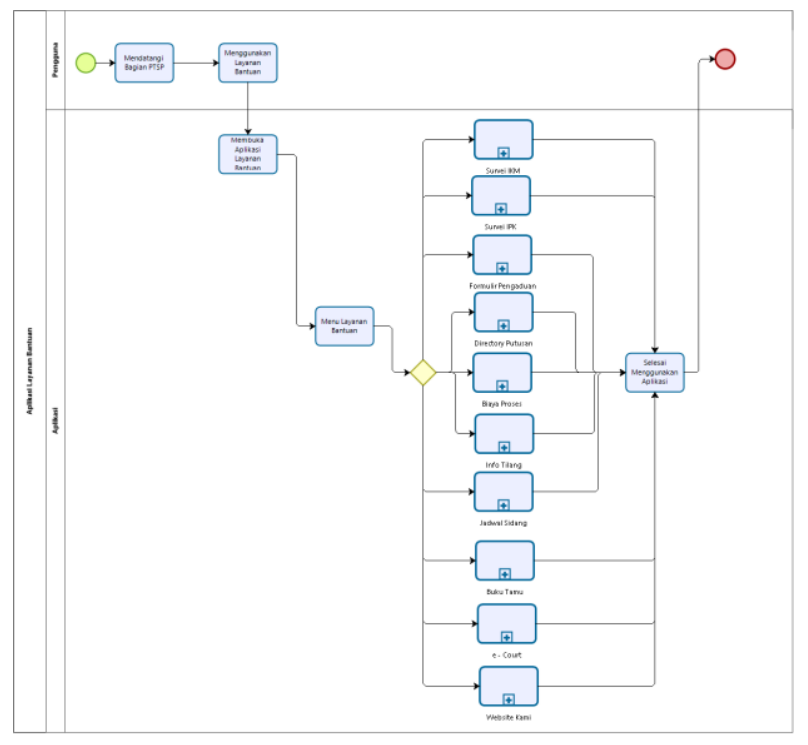

Gbr. 1 Proses Bisnis Aplikasi Layanan Bantuan Pengadilan Negeri Tondano

\section{Analyze the Findings}

Keuntungan dari sistem lama :

- Pegawai sudah terbiasa dengan sistem yang ada.

Kelemahan dari sistem lama :

- Menggunakan proses secara manual.

- Membutuhkan waktu yang cukup lama.

Setelah menganalisis sistem yang lama, maka kami simpulkan bahwa Pengadilan Negeri Tondano membutuhkan 
aplikasi mobile layanan bantuan yang berbasis android untuk proses pengisian Survei IPK, IKM, buku tamu, memberikan informasi secara akurat dan mampu menjaga keamana data.

\section{Phase 3 : Design}

a) Design Database

Pada aplikasi ini kami tidak menggunakan database karena aplikasi mobile layanan bantuan pengadilan negeri tondano ini hanya menghubungkan link ke link dari aplikasi dan website yang telah dibuat oleh pengadilan negeri tondano sebelumnya.

b) User Interface Design

Pada tahapan rancangan aplikasi ini, Kami akan merancang aplikasi ini berdasarkan flow dan proses bisnis yang telah kami rancang sebelumnya. Berikut adalah tampilan-tampilan pada aplikasi :

- Tampilan Splash Screen

Pada tampilan Splash Screen ini akan menampilkan logo pengadilan negeri tondano dengan latar belakang gambar gedung pengadilan negeri tondano dengan interval waktunya 1 detik.

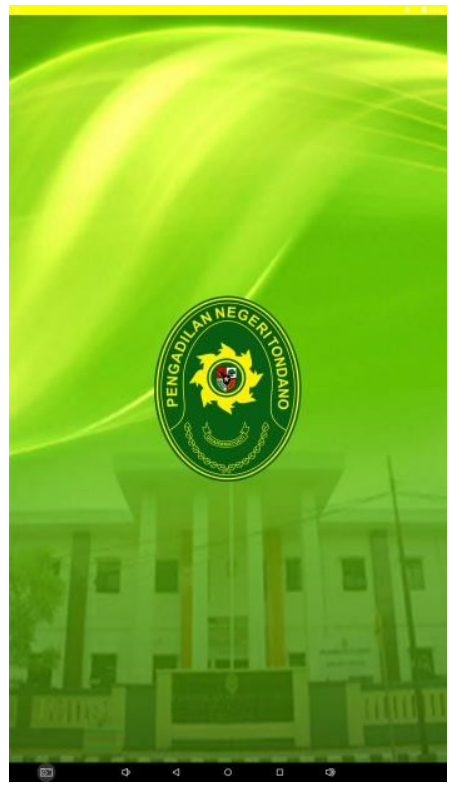

Gbr. 1 Tampilan Splash Screen Aplikasi Layanan Bantuan

- Tampilan Menu Utama

Pada Tampilan menu utama ini menampilkan menu-menu yang ada pada aplikasi. Adapun menu-menunya terdiri dari :

- $\quad$ Menu Survei IKM

- Menu Survei IPK

- Menu Formulir Pengaduan

- Menu Direktori Putusan
- Menu Biaya Proses

- Menu Info Tilang

- Menu Jadwal Sidang

- $\quad$ Menu Buku Tamu

- Menu E-Court

- $\quad$ Menu Website Kami

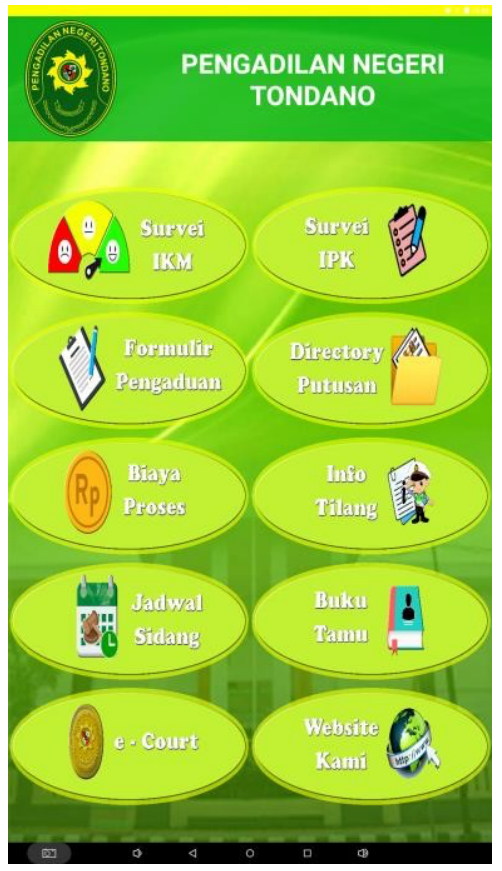

Gbr. 3 Tampilan Menu Utama Aplikasi Layanan Bantuan

4. Phase 4 : Integrasi dan Pengujuan (Integration and Test) Pada tahap ini kami menggunakan pengujian black box sebagai hasil dari mendemonstrasikan perangkat lunak bahwa telah memenuhi kebutuhan yang dispesifikasikan pada dokumen kebutuhan fungsional.
TABEL II. ANALYZE USER

\begin{tabular}{|c|l|l|l|}
\hline \multicolumn{1}{|c|}{ Input } & \multicolumn{1}{|c|}{ Proses } & \multicolumn{1}{c|}{ Output } & Hasil Uji \\
\hline Klikicon & Masuk ke & Menampilkan & Berhasil \\
aplikasi & aplikasi & splash screen & \\
layanan & & selama 3 detik & \\
bantuan & & kemudian & \\
& & masuk ke & \\
& & menu utama & \\
\hline
\end{tabular}




\begin{tabular}{|c|c|c|c|}
\hline $\begin{array}{l}\text { Klik } \\
\text { menu } \\
\text { survei } \\
\text { indeks } \\
\text { kepuasa } \\
n \\
\text { masyara } \\
\text { kat } \\
\text { (IKM) }\end{array}$ & $\begin{array}{l}\text { Masuk ke } \\
\text { menu } \\
\text { survei } \\
\text { IKM }\end{array}$ & $\begin{array}{l}\text { Menampilkan } \\
\text { kuesioner } \\
\text { indeks } \\
\text { persepsi } \\
\text { masyarakat }\end{array}$ & Berhasil \\
\hline $\begin{array}{l}\text { Klik } \\
\text { menu } \\
\text { survei } \\
\text { indeks } \\
\text { persepsi } \\
\text { korupsi } \\
\text { (IPK) }\end{array}$ & $\begin{array}{l}\text { Masuk ke } \\
\text { menu } \\
\text { survei IPK }\end{array}$ & $\begin{array}{l}\text { Menampilkan } \\
\text { kuesioner } \\
\text { indeks } \\
\text { persepsi } \\
\text { korupsi }\end{array}$ & Berhasil \\
\hline $\begin{array}{l}\text { Klik } \\
\text { menu } \\
\text { formulir } \\
\text { pengadu } \\
\text { an }\end{array}$ & $\begin{array}{l}\text { Masuk ke } \\
\text { menu } \\
\text { formulir } \\
\text { pengadua } \\
n\end{array}$ & $\begin{array}{l}\text { Menampilkan } \\
\text { website sistem } \\
\text { informasi } \\
\text { pengawasan } \\
\text { badan } \\
\text { pengawasan } \\
\text { mahkamah } \\
\text { agung } \\
\text { republik } \\
\text { Indonesia } \\
\text { (SIWAS) }\end{array}$ & Berhasil \\
\hline $\begin{array}{l}\text { Klik } \\
\text { menu } \\
\text { direktori } \\
\text { putusan }\end{array}$ & $\begin{array}{l}\text { Masuk ke } \\
\text { menu } \\
\text { direktori } \\
\text { putusan }\end{array}$ & $\begin{array}{l}\text { Menampilkan } \\
\text { website } \\
\text { direktori } \\
\text { putusan } \\
\text { mahkamah } \\
\text { agung } \\
\text { republic } \\
\text { indonesia }\end{array}$ & Berhasil \\
\hline $\begin{array}{l}\text { Klik } \\
\text { menu } \\
\text { biaya } \\
\text { proses }\end{array}$ & $\begin{array}{l}\text { Masuk ke } \\
\text { menu } \\
\text { biaya } \\
\text { proses }\end{array}$ & $\begin{array}{l}\text { Menampilkan } \\
\text { list biaya } \\
\text { proses dari } \\
\text { tiap-tiap } \\
\text { perkara }\end{array}$ & Berhasil \\
\hline $\begin{array}{l}\text { Klik } \\
\text { menu } \\
\text { info } \\
\text { tilang }\end{array}$ & $\begin{array}{l}\text { Masuk ke } \\
\text { menu info } \\
\text { tilang }\end{array}$ & $\begin{array}{l}\text { Menampilkan } \\
\text { info tilang } \\
\text { pada website } \\
\text { sistem } \\
\text { informasi } \\
\text { penelusuran } \\
\text { perkara } \\
(\text { SIPP) }\end{array}$ & Berhasil \\
\hline $\begin{array}{l}\text { Klik } \\
\text { menu } \\
\text { jadwal } \\
\text { sidang }\end{array}$ & $\begin{array}{l}\text { Masuk ke } \\
\text { menu } \\
\text { jadwal } \\
\text { sidang }\end{array}$ & $\begin{array}{l}\text { Menampilkan } \\
\text { jadwal sidang } \\
\text { pada website } \\
\text { sistem } \\
\text { informasi } \\
\text { penelusuran } \\
\text { perkara } \\
(\text { SIPP) }\end{array}$ & Berhasil \\
\hline $\begin{array}{l}\text { Klik } \\
\text { menu } \\
\text { buku } \\
\text { tamu }\end{array}$ & $\begin{array}{l}\text { Masuk ke } \\
\text { menu buku } \\
\text { tamu }\end{array}$ & $\begin{array}{l}\text { Menampilkan } \\
\text { buku tamu } \\
\text { elektronik } \\
\text { melalui } \\
\text { google for }\end{array}$ & Berhasil \\
\hline
\end{tabular}

\begin{tabular}{|l|l|l|l|}
\hline $\begin{array}{l}\text { Klik } \\
\text { menu e- } \\
\text { Court }\end{array}$ & $\begin{array}{l}\text { Masek ke } \\
\text { menu e- } \\
\text { Court }\end{array}$ & $\begin{array}{l}\text { Menampilkan } \\
\text { website e- } \\
\text { Court } \\
\text { mahkamah } \\
\text { agung RI }\end{array}$ & Berhasil \\
\hline $\begin{array}{l}\text { Klik } \\
\text { menu } \\
\text { website } \\
\text { kami }\end{array}$ & $\begin{array}{l}\text { Masuk ke } \\
\text { menu } \\
\text { website } \\
\text { kami }\end{array}$ & $\begin{array}{l}\text { Menampilkan } \\
\text { website } \\
\text { pengadilan } \\
\text { negeri } \\
\text { tondano }\end{array}$ & Berhasil \\
\hline
\end{tabular}

Pengujian black box ini dilakukan oleh :

Sekretaris Pengadilan Negeri Tondano

- Nani F. Maslukman, SH

Hakim Pengadilan Negeri Tondano

- Frans W. S. Pangemanan, SH., MH.

Kesimpulan dari hasil pengujian black box pada aplikasi layanan bantuan Pengadilan Negeri Tondano adalah 100\% pengujian aplikasi berhasil.

\section{KESIMPULAN}

Sebagai produk luaran kerja praktek kami telah membuat aplikasi mobile dengan nama layanan bantuan pengadilan negeri tondano berbasis android, dengan menggunakan metode System Development Life Cycle (SDLC). Aplikasi ini dirancang menggunakan MIT App Inventor. Aplikasi ini membantu pengadilan negeri tondano khususnya bagian pelayanan terpadu satu pintu (PTSP) dalam menjalankan system layanan bantuan bagi pencari keadilan.

\section{DAFTAR PUSTAKA}

[1] A.S Rosa, dan M.Shalahuddin. 2018. Rekayasa Perangkat Lunak Struktur dan Berorientasi Objek. Bandung : Informatika

[2] http://adrianti.staff.gunadarma.ac.id/Downloads/files/37901/SDLC.pdf -> metode penelitian

[3] https://www.dosenpendidikan.co.id/pengertian-aplikasi-menurut-paraahli/

[4] http://jamesthoengsal.blogspot.com/p/life-cicle-projectconstruction.html

[5] http://jurnal.atmaluhur.ac.id/index.php/TI_atma_luhur/ article/view/220/182 